\title{
CANCER, POVERTY AND LACK OF ACCESS TO THE BEST THERAPIES IN BRAZIL
}

\section{EDITORIAL}

\author{
Running head: ACCESS TO THE BEST THERAPIES IN BRAZIL
}

Fernando Barroso Duarte', Anna Thawanny Gadelha Moura², Romélia Pinheiro Gonçalves Lemes2.

\section{Clinical Hospital, Department of surgery - Federal University of Ceara, Fortaleza, Brazil - 2 Hematology Research Laboratory - Federal University of Ceara, Fortaleza, Brazil.}

Correspondence to: Anna Thawanny Gadelha Moura. Research Laboratory in Hemoglobinopathies and Genetics of Hematologic Diseases - Federal University of Ceara. Capitão Francisco Pedro, street, n. 1210Rodolfo Teófilo. Zip code: 60430-370 - Fortaleza - Ceará Brazil. Email: thawanny.anna@gmailcom.

This year, I followed a young patient who is being investigated for a probable leukemia,[1] He said he was a gardener. I tried to explain what his diagnostic hypothesis was, but I had a distinct feeling that he hadn't quite understood the situation. I always feel this feeling of anguish, a certain impotence, because the exact understanding involves a minimum amount of knowledge that this gentleman must have about health, citizenship or even general education, which a good part of the population that we treat in public hospitals does not have.

This patient who does not understand his illness very well and what effectively needs to be done for a correct diagnosis and treatment. Added to this is the difficulty of having access to new expensive drugs and, as if that were not enough, some essential drugs for the treatment of cancer, such as carmustine[2], used to conditioning regimen of Bone Marrow transplant, which simply disappeared from the Brazilian market and left with restrict options to treat these patients.

In any case, it is not the first time that we have dealt with this reality, and many will say that there is nothing new in my report or that it used to be much worse. I agree with these two statements, but this process remains very difficult, painful and very worrying. When a patient has a cancer diagnosis and needs a treatment that doesn't have another option, we see clearly that it's necessary discuss this reality and try to find a solution. I participated in february of a congress in the United States; there I could see the main updates in the treatments of onco-hematology and bone marrow transplantation. I presented an article[3] and, throughout the debate, I tried to show my professional colleagues the profound differences, not to say abysmal, between our realities in Latin America and first world countries. This distance becomes increasingly larger as treatment progresses based on targeted and cellular therapies, with drugs such as immunotherapy associated with chemotherapy or the use of "smart" cells that destroy cancer, which are difficult to access.

Thus, we come to the difficult trinomial that consists of cancer, poverty and lack of access. This leads us to a deep reflection on the real paths we are taking and where this modern, technological and fast society will take us all, if we do not pay attention to the need to place the individual as the priority center of all our actions.

\section{CONFLICT OF INTEREST}

The authors have no competing interests.

\section{REFERENCES}

1. Campo E, Swerdlow SH, Harris NL, et al. The 2008 WHO classification of lymphoid neoplasms and beyond: evolving concepts and practical applications. Blood. 2011 v.117, p.: 5019-5032.

2. Ádám J, Zsófia M, Szilárd P, et al. Effect of Bleomycin Hydrolase Gene Polymorphism on Late Pulmonary Complications of Treatment for Hodgkin Lymphoma. PLoS One. 2016; v. 11, p.: e0157651.

3. Duarte FB, Moura ATG, Funke VAM, et al. Impact of treatment prior to Allogeneic Transplantation of Hematopoietic stem cells in patients with myelodysplastic syndrome: results of the latin american bone marrow transplant registry. Biol Blood Marrow Transplant. 2020;v.20, p1083-8791. 